\title{
Hydrochemistry and Water Quality Indices of River Ose Water, Southern Nigeria
}

\author{
Abel. Ojo. Talabi \\ Department of Geology, Ekiti State University \\ Ado-Ekiti, Ekiti State, Nigeria \\ Email: abel.talabi [AT] eksu.edu.ng
}

\begin{abstract}
----
Background Objective: River Ose has flowing water throughout the year that can serve for irrigation and domestic purposes. This study examined the hydrochemistry, water quality indices and coliform counts of River Ose Water, Nigeria with a view to ascertain its suitability for drinking and irrigation.

Materials and Method: For this purpose, 15 water samples were collected along the flowing river channel and subjected to physico-chemical and Escherichia coli (E. coli) determination using standard methods. Water quality index (WQI) and Irrigation parameters (Sodium adsorption ratio (SAR), Percentage sodium (\%Na), Residual sodium bicarbonate (RSBC), Kelly's ratio (KR), Permeability index (PI) and Magnesium absorption ratio (MAR)) were calculated from the chemical data obtained from the analyses.

Results: Results of the analyses revealed that $p H(9.7 \geq p H \leq 10.6)$ of the water samples were of alkaline nature with all the water samples exceeding approved standard for drinking water. Drinking alkaline water may deactivate pepsin but it could lead to gastrointestinal problems and metabolic alkalosis. Electrical conductivity ( $\mu$ S/cm), Total dissolved solids (mg/L) as well as Total hardness of all analyzed water samples fell in the category of fresh water. $\mathrm{HCO}_{3}^{-}$and $\mathrm{Cl}^{-}$ were the dominant anions while $\mathrm{Na}^{+}$and $\mathrm{K}^{+}$constituted the dominant cations in the water chemistry. The abundance of major ions revealed $\mathrm{Na}^{+}>\mathrm{K}^{+}>\mathrm{Mg}^{2+}>\mathrm{Ca}^{2+}$ and $\mathrm{HCO}_{3}^{-}>\mathrm{Cl}^{-}>\mathrm{SO}_{4}{ }^{2-}>\mathrm{NO}_{3}^{-}$trend. The dominant hydrogeochemical facies was mixed $\mathrm{Ca}^{2+}-\mathrm{Na}^{+}-\mathrm{HCO}_{3}^{-}(93 \%)$ with few mixed $\mathrm{Ca}^{2+}-\mathrm{Mg}^{2+}-\mathrm{Cl}$ (7\%) while calculated WQI was 89.44 . All samples tested positive to $E$. coli determination with values ranging from $1.71 * 10^{1}-8.100 * 10^{3}(\mathrm{cfu} / \mathrm{ml})$.

Conclusion: The analyzed physico-chemical parameters in all River Ose water samples were well within approved desirable limits except for the $\mathrm{pH}$. However, the water was not potable as all samples tested positive to E. coli counts. In addition, WQI calculation revealed that the water had very poor drinking quality. Sources of ions in the River were predominantly from rainfall and minor weathering from the bedrocks. Irrigation quality parameters (SAR, \%Na, RSBC and KR) indicated that River Ose water was good for irrigation. However, applying the water on salt sensitive plants is not advisable as irrigation evaluation employing PI and MAR showed that the water was not suitable for irrigation.
\end{abstract}

Keywords - Flowing water, physico-chemical, irrigation parameters, major ions, hydrogeochemical facies.

Competing interest: The Author has declared that no competing interest with respect to this manuscript.

Data availability: All relevant data pertaining to this manuscript are included in the paper

\section{INTRODUCTION}

Access to clean water is a human right and a basic requirement for economic development. Water is the liquid of life that quantity as well as quality requirements are essential for continuity of life and eco-system sustainability. Improvement in human health as well as agricultural yields depends much on the quantity and quality of water used for drinking and irrigation. Rivers that constitute major sources of surface water used for drinking and irrigation purposes are environmentally vulnerable to contamination as wastes (agricultural, industrial and domestic) are often dumped in them.

Several scientific reports on water quality effects on human, agricultural and industrial applications all around the world have been published [1, 2, 3, 4, 5, 6, 7, 8, 9]. A study by [10] on the hydrochemical and heavy metal concentration in the soil and water resources of Hamadan province of Iran during which the concentrations of cadmium (Cd), copper $(\mathrm{Cu})$, lead $(\mathrm{Pb})$ and zinc $(\mathrm{Zn})$ as important parameters for developing the agricultural development projects were measured, concluded that the potential of studied area was suitable for developing the agricultural projects because the values of the parameters were under standard indices. Also, [11] on Measurement of cytotoxicity and heavy metal load in drains water receiving textile effluents and drinking water in vicinity of drains revealed that the water quality parameters were beyond the permissible limit and textile industries significantly contributed in contamination of ground water with $\mathrm{Pb}$ and $\mathrm{Cd}$ metals. In developing countries, most of which have huge debt burdens, population explosion and 
moderate to rapid urbanization, people have little or no option but to accept water sources of doubtful quality, due to lack of better alternative sources or due to economic and technological constraints to treat the available water adequately before use $[12,13]$. The scarcity of clean water and pollution of fresh water has therefore led to a situation in which onefifth of the urban dwellers in developing countries and three quarters of their rural dwelling population do not have access to reasonably safe water supplies [14].

Nigeria has an estimated total actual renewable water resources of $286.2 \mathrm{~km}^{3} /$ year amounting to $1893 \mathrm{~m}^{3} / \mathrm{year}$ per capital [15]. The total area occupied by water in Nigeria is $13,000 \mathrm{~km}^{2}$. Nigeria has abundant water resources covering an enormous and diverse landscape, although they are unevenly distributed over the country [16]. The space occupied by inland water bodies in Nigeria is estimated at $900 \mathrm{~km}^{2}$ [17]. Available literature on environmental monitoring of surface water indicated that streams and rivers in the country are showing increasing trend of water pollution due to increase population, industrialization and urbanization. Waste generations by the industries and households have continued to increase. These wastes are indiscriminately disposed-off into the water bodies which has led to pollution of inland water bodies and coastal waters and subsequently increased water quality parameters such as heavy metals, nutrients and organic matter, soluble ions, oil and grease and organic chemicals such as pesticides and poly-nuclear aromatic hydrocarbons $[18,19,20,21,22]$. Urgent attention is therefore necessary to mitigate water pollution problems in Nigeria through monitoring as well as enforcement of emission standards by industries [17].

River Ose originated in the Akpata hills in Ekiti State, Nigeria. It flows through Ovia North-East Local Government Area and empties into the Benin River, which is one of the four major rivers that drain into the Atlantic Bight of Benin [23]. River Ose water has been very useful serving many local communities for drinking and irrigation purposes. Public water supply for Owo, Iyere, Isuada, Ipele and Emure-Ile is from a Dam built across River Ose. The Ose water works which supply water to the communities in the listed towns has a capacity of 2,250 cubic meters per day, out of which about $2,000 \mathrm{~m}^{3}$ is consumed by Owo in Ondo State, Nigeria. The River Ose serves as secondary source of piped borne water supply to the city [24].

Land management and the physical environment through which the river flows have untold influence on their quality. The upper stream of the river passes through Basement terrains while the downstream where water samples were taken for this study flows through the transition zone (Basement /sedimentary). Contamination of such body of water could be geogenic, anthropogenic or combined geogenic/anthropogenic. Anthropogenic is consequent of pollutants input arising from societal activities. Thus, understanding the quality conditions of river Ose is critical if the farmers and the entire Ose community are to develop effective plans to maintain continuous supply of agricultural products without abating especially during the dry season. Hence, this study focused on "the Hydrochemistry and Water quality Indices of River Ose, Southern Nigeria" with a view to ascertain its suitability for drinking and agricultural purposes.

\section{LOCATION OF STUDY}

River Ose is a stream (class H - Hydrographic) in Nigeria, located at an elevation of 136 meters above sea level. The study portion of the river is located on latitude $6^{\circ} 47^{\prime} 23^{\prime \prime} \mathrm{N}-6^{\circ} 50^{\prime} 00^{\prime \prime}$ and longitude $5^{\circ} 45^{\prime} 00^{\prime \prime} \mathrm{E}-5^{\circ} 48^{\prime} 25^{\prime \prime} \mathrm{E}$ in Edo State of Nigeria (Fig. 1). The climate is of the humid tropical wet and dry seasons. Increased flow rate, high turbidity and muddy water especially after heavy rainfall occur during the wet season while the river is characterized by moderate or slow flow rate and clearer water during the dry season. Several streams and creeks drain into River Ose and the river is the major source of drinking water for the inhabitants of communities surrounding it [25]. The study area has an average relative humidity of $80.5 \%$ with mean annual rainfall of $2200 \mathrm{~mm}$. Temperature is high throughout the year with mean value of $34^{\circ} \mathrm{C}$ for the hottest months (February/March) and $28^{\circ} \mathrm{C}$ for the coolest month (August) [23]. The study location is in a transition zone between the Basement Complex and Dahomey Basin. However, rock exposures along the river are mainly migmatites and older granites. Sandstone and clay of Quaternary age overlay the Basement rocks.

\section{MATERIALS AND METHODS}

To evaluate the water quality of Ose River, 15 water samples (Fig. 1) were collected along the river channel into preconditioned polyethylene bottles for hydrochemical investigations in the dry season, February, 2017. The temperature $\left(\mathrm{T}{ }^{\circ} \mathrm{C}\right), \mathrm{pH}$, specific conductivity $(\mathrm{EC}(\mu \mathrm{S} / \mathrm{cm}))$ were measured insitu using portable electrical conductivity meter. Major ions and Faecal coliform of the sampled water were analyzed in the Laboratory following American Public Health Association guidelines [26]. Cations determination was by Atomic Absorption Spectrophotometer (Varian - AA240) while the anions was by Colorimetric method using DR 5000 Spectrophotometer (Hach, USA). For Faecal Coliform estimations, multiple fermentation tubes containing MacConkey broth were inoculated with $1 \mathrm{ml}$ of sample and incubated at $44^{\circ} \mathrm{C}$ for $48 \mathrm{hr}$. The E. coli count was evaluated using standard methods [27] and [28]. Total hardness (TH) was estimated using: TH $(\mathrm{mg} / \mathrm{L})=2: 497 \mathrm{Ca}^{2+}+4: 115 \mathrm{Mg}^{2+}[29]$ and TDS $(\mathrm{mg} / \mathrm{L}) \approx 0.67 \times \mathrm{EC}(\mu \mathrm{S} / \mathrm{cm})[30]$. Statistical evaluation of the data from the analyses was carried out employing Microsoft Office Excel 2007. Correlation between 
selected water quality parameters was carried out using Paleontological Statistics (PAST) Version 3.14. Piper and Schoeler diagrams were obtained using GW_Chart and Microsoft Office Excel 2007 respectively.

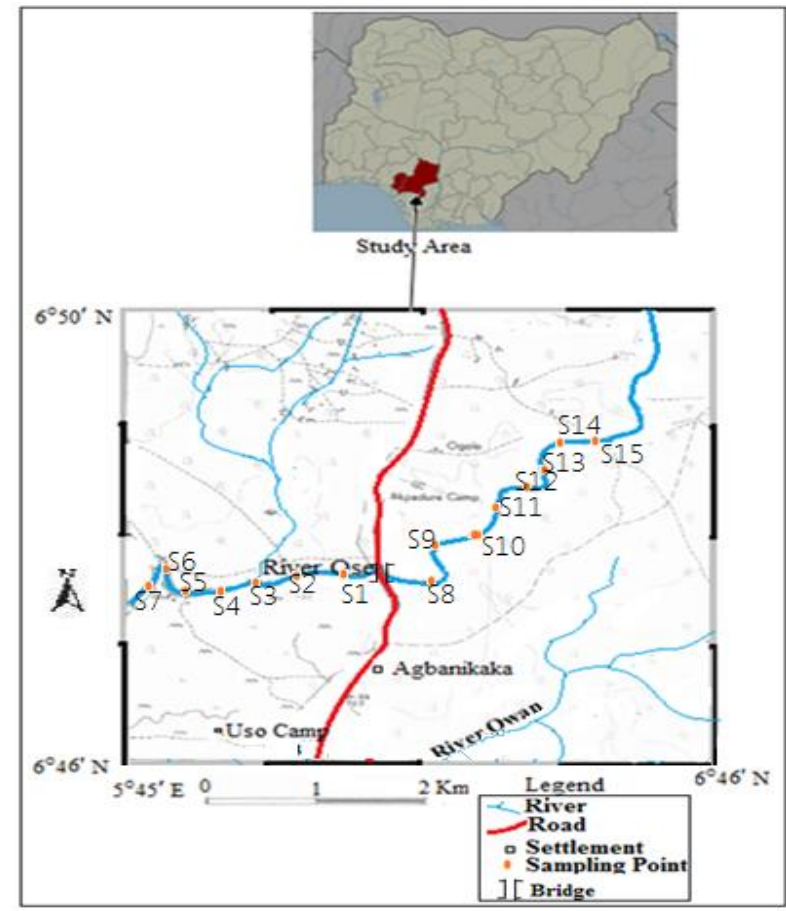

Figure 1: Location Map

Water quality index (WQI) of all the 15 samples from River Ose have been calculated to find its suitability for drinking purposes by Weight Arithmetic using 11 water quality parameters (pH, EC, TDS, TH, $\mathrm{NO}_{3}, \mathrm{SO}_{4}, \mathrm{Cl}, \mathrm{Ca}, \mathrm{Mg}, \mathrm{Na}$ and $\mathrm{K}$ ). The calculation of the WQI was done using weighted arithmetic water quality index which was originally proposed by [31] and developed by [32]. The weighted arithmetic water quality index $\left(\mathrm{WQI}_{\mathrm{A}}\right)$ was estimated using the following formula:

$$
\sum_{i=1}^{n} \text { wiqi } / \sum_{i=1}^{n} \text { wi } 1
$$

where $n$ is the number of variables or parameters, wi is the relative weight of the $i$ th parameter and $\mathrm{q}_{\mathrm{i}}$ is the water quality rating of the ith parameter. The unit weight ( $w \mathrm{i}$ ) of the various water quality parameters are inversely proportional to the recommended standards for the corresponding parameters. According to [32], the value of $q \mathrm{i}$ is calculated using the following equation:

$$
q_{i}=100[(\mathrm{Vi}-\mathrm{Vid}) /(\mathrm{Si}-\mathrm{Vid})]
$$

where $\mathrm{Vi}$ is the observed value of the ith parameter, $\mathrm{Si}$ is the standard permissible value of the ith parameter and Vid is the ideal value of the ith parameter in pure water (Table 4). All the ideal values (Vid) are taken as zero for drinking water except $\mathrm{pH}$ and dissolved oxygen [33]. For $\mathrm{pH}$, the ideal value is 7.0 (for natural/pure water) and a permissible value is 8.5 (for polluted water). Therefore, the quality rating for $\mathrm{pH}$ is calculated from the following equation:

$$
q_{p H}=100[(V p H-7.0) /(8.5-7.0)]
$$

where $\mathrm{VpH}=$ observed value of $\mathrm{pH}$. Calculation of $\mathrm{q}_{\mathrm{i}}$ for the rest parameters were carried out following similar procedures. Employing equation 1, WQI was obtained for the river.

Irrigation parameters (sodium adsorption ratio (SAR), sodium percentage $(\mathrm{Na} \%)$, Residual sodium bicarbonate (RSBC), Permeability Index (PI), Magnesium Absorption Ratio (MAR) and Kelly Ratio (KR) were determined to assess the suitability of River Ose water for irrigation purposes.

\section{RESULTS AND DISCUSSION}

The results of analyzed River Ose water samples are presented in Tables 1 and 2. The $\mathrm{pH}$ of the analyzed River Ose water samples varied from 9.70 to 10.60 (av. 9.99) indicating the alkaline nature of the water. Drinking alkaline water with a pH of 8.8 may help deactivate pepsin which is the main enzyme that causes acid reflux. However, reports by the 
World Health Organization indicated that alkaline water with a pH higher than 11 may cause gastrointestinal problems, irritate eyes, skin and mucous membranes. Drinking too much alkaline water or drinking water with a high $\mathrm{pH}$, may disrupt the body's normal $\mathrm{pH}$ which can lead to a condition called metabolic alkalosis, causing confusion, nausea, vomiting, hand tremors, muscle twitching and tingling in the face, hands or feet.

Electrical conductivity (EC) is a reflection of the conducting capacity of water which in turn is determined by the presence of dissolved ions. Higher the ionisable solids, greater will be the EC. EC is a measure of total dissolved solids (TDS) i.e. it depends upon the ionic strength of the solution. Increase in the concentration of dissolved solids, increases the ionic strength of the solution [34]. The measured EC of River Ose water varied from 92 to 203 (av. 120.33) $\mu \mathrm{S} / \mathrm{cm}$. Concentration of total dissolved solids (TDS) in the River Ose water ranged from 59.80 to 131.95 (av. 78.22) (Table 1). Water can be classified into fresh (TDS $<1,000 \mathrm{mg} / \mathrm{L})$, brackish $(>1,000 \mathrm{mg} / \mathrm{L})$, saline $(>10,000 \mathrm{mg} / \mathrm{L})$ and brine $(100$, $000 \mathrm{mg} / \mathrm{L}$ ) categories on the basis of TDS concentration [35]. Based on this classification, River Ose water fell into fresh water category.

Table 1: Physical Parameters and E. coli counts of sampled water from Ose River

\begin{tabular}{|c|c|c|c|c|c|c|c|}
\hline Code & $\begin{array}{l}\text { Temp. } \\
\left({ }^{\circ} \mathrm{C}\right)\end{array}$ & pH & $\begin{array}{l}\mathrm{EC} \\
(\mu \mathrm{S} / \mathrm{cm})\end{array}$ & $\begin{array}{l}\text { TDS } \\
\mathrm{mg} / \mathrm{l}\end{array}$ & $\begin{array}{l}\text { TH } \\
(\mathrm{mg} / \mathrm{L})\end{array}$ & Alkalinity & $\begin{array}{l}\text { E. Coli } \\
(\mathrm{cfu} / \mathrm{ml})\end{array}$ \\
\hline OS1 & 30.80 & 10.10 & 96.00 & 62.40 & 16.32 & 61.00 & $1.7 * 10^{1}$ \\
\hline OS2 & 32.00 & 10.30 & 97.00 & 63.05 & 17.09 & 61.00 & $2.8 * 10^{1}$ \\
\hline OS3 & 31.20 & 10.30 & 93.00 & 60.45 & 15.58 & 50.83 & $4.1 * 10^{1}$ \\
\hline OS4 & 31.60 & 10.20 & 92.00 & 59.80 & 16.87 & 61.00 & $3.1 * 10^{1}$ \\
\hline OS5 & 31.50 & 10.00 & 93.00 & 60.45 & 17.25 & 61.00 & $1.080 * 10^{3}$ \\
\hline OS6 & 31.50 & 9.90 & 92.00 & 59.80 & 17.03 & 81.33 & $6.70 * 10^{2}$ \\
\hline OS7 & 30.90 & 9.80 & 133.00 & 86.45 & 17.33 & 71.17 & $8.30 * 10^{2}$ \\
\hline OS8 & 31.50 & 9.70 & 120.00 & 78.00 & 17.30 & 50.83 & $7.40 * 10^{2}$ \\
\hline OS9 & 31.90 & 9.70 & 94.00 & 61.10 & 16.07 & 61.00 & $3.200 * 10^{3}$ \\
\hline OS 10 & 31.20 & 9.70 & 108.00 & 70.20 & 15.21 & 71.17 & $2.200 * 10^{3}$ \\
\hline OS11 & 31.80 & 9.90 & 92.00 & 59.80 & 15.83 & 50.83 & $4.300 * 10^{3}$ \\
\hline OS 12 & 32.00 & 9.80 & 146.00 & 94.90 & 17.01 & 71.17 & $6.400 * 10^{3}$ \\
\hline OS13 & 30.90 & 10.10 & 196.00 & 127.40 & 15.96 & 50.83 & $7.200 * 10^{3}$ \\
\hline OS 14 & 32.00 & 9.70 & 203.00 & 131.95 & 17.05 & 61.00 & $8.100 * 10^{3}$ \\
\hline OS15 & 31.50 & 10.60 & 150.00 & 97.50 & 15.52 & 71.17 & $1.60 * 10^{2}$ \\
\hline Min & 30.80 & 9.70 & 92.00 & 59.80 & 15.21 & 50.83 & $1.7 * 10^{1}$ \\
\hline Max & 32.00 & 10.60 & 203.00 & 131.95 & 17.33 & 81.33 & $8.100 * 10^{3}$ \\
\hline Mean & 31.49 & 9.99 & 120.33 & 78.22 & 16.49 & 62.36 & $2.333 * 10^{3}$ \\
\hline Stdev & 0.41 & 0.27 & 37.93 & 24.66 & 0.74 & 9.31 & $2.844 * 10^{3}$ \\
\hline [36] & - & $6.5-9.5$ & 1500 & 1000 & 500 & & 0.00 \\
\hline
\end{tabular}

\subsection{Major Ions chemistry}

Among the anions, $\mathrm{HCO}_{3}{ }^{-}$has the dominant ionic concentration followed by $\mathrm{Cl}^{-}$with $\mathrm{NO}_{3}{ }^{-}$being the ions with least concentration. The order of anions abundance in River Ose water was found as $\mathrm{HCO}_{3}{ }^{-}>\mathrm{Cl}^{-}>\mathrm{SO}_{4}{ }^{2-}>\mathrm{NO}_{3}{ }^{-}(\mathrm{Fig} .2)$. Among major cations, $\mathrm{Na}^{+}$and $\mathrm{K}^{+}$were the dominant ions followed by $\mathrm{Ca}^{2+}$ and $\mathrm{Mg}^{2+}$ respectively. The order of cations abundance was $\mathrm{Na}^{+}>\mathrm{K}^{+}>\mathrm{Ca}^{2+}>\mathrm{Mg}^{2+}$. 

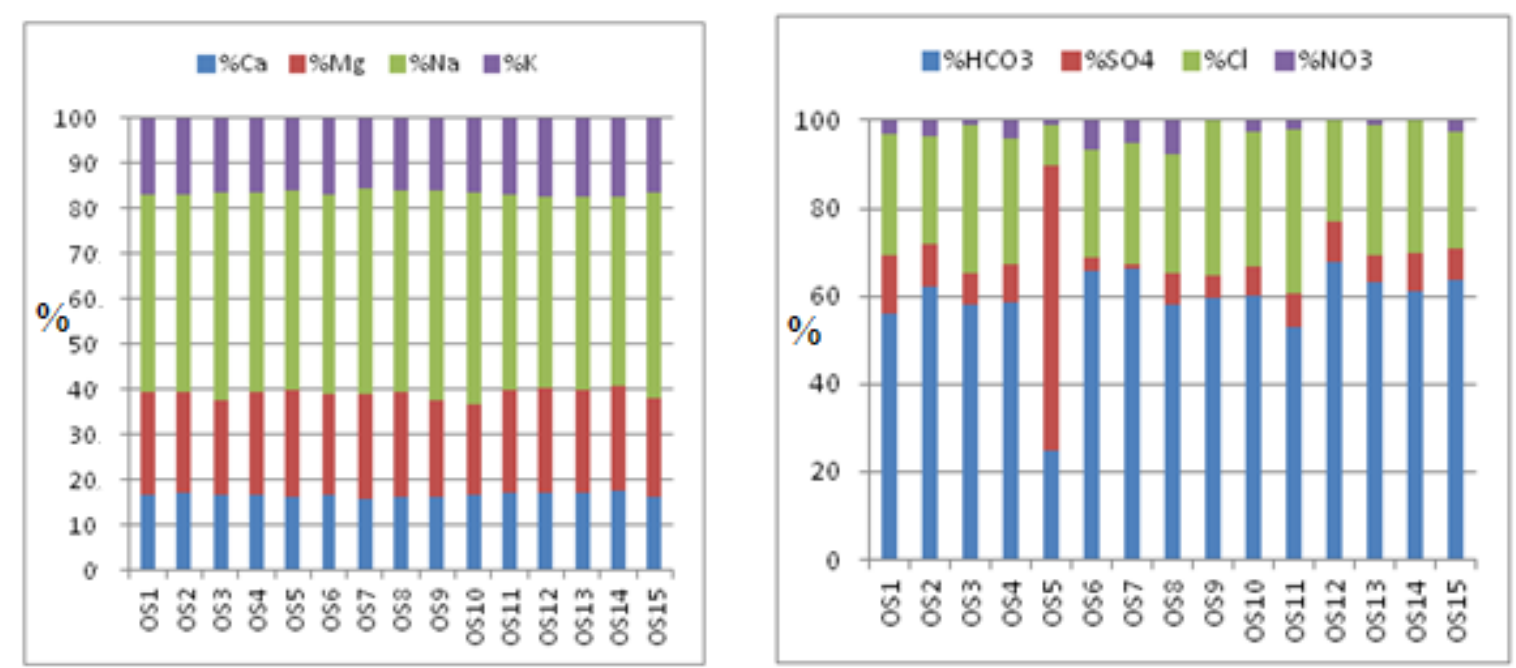

Figure 2: Changes in cations and anions concentrations along the flow path

The ions dominance was further reflected in Schoeller diagram (Fig.3) and Piper Trilinear diagram (Fig. 4). The Schoeller diagram [37] permits the cations and anions of many samples to be represented on a single graph in which major groupings or trends in the data can be discerned visually. The Schoeller semi logarithmic diagram shows the total concentrations of the cations and anions (Fig. 4). The Schoeller diagram in this research clearly revealed $\mathrm{HCO}_{3}{ }^{-}$and $\mathrm{Cl}^{-}$ as dominant anions while $\mathrm{Na}^{+}$was the dominant cation. The Piper Diagram [38], represents combination of anions and cations triangles that lie on a common baseline with a diamond shape between them. The diagram can be used to make a tentative conclusion as to the origin of the water represented by the analysis and to characterize different water types [39]. The Piper diagram divided waters into four basic types according to their placement near the four corners of the diamond (Fig. 4). The Piper diagram revealed dominant mixed $\mathrm{Ca}^{2+}-\mathrm{Na}^{+}-\mathrm{HCO}_{3}{ }^{-}$type with mixed $\mathrm{Ca}^{2+}-\mathrm{Mg}^{2+}-\mathrm{Cl}^{-}$in the minority in this study.

Table 2: Chemical parameters of sampled River Ose Water

\begin{tabular}{l|llllllllll}
\hline Code & $\begin{array}{l}\mathbf{C a} \\
(\mathbf{m g} / \mathbf{L})\end{array}$ & $\begin{array}{l}\mathbf{M g} \\
(\mathbf{m g} / \mathbf{L})\end{array}$ & $\begin{array}{l}\mathbf{N a} \\
(\mathbf{m g} / \mathbf{L})\end{array}$ & $\begin{array}{l}\mathbf{K} \\
(\mathbf{m g} / \mathbf{L})\end{array}$ & $\begin{array}{l}\mathbf{M n} \\
(\mathbf{m g} / \mathbf{L})\end{array}$ & $\begin{array}{l}\mathbf{F e} \\
(\mathbf{m g} / \mathbf{L})\end{array}$ & $\begin{array}{l}\mathbf{H C O 3} \\
(\mathbf{m g} / \mathbf{L})\end{array}$ & $\begin{array}{l}\mathbf{S O}_{4} \\
(\mathbf{m g} / \mathbf{L})\end{array}$ & $\begin{array}{l}\mathbf{C l} \\
(\mathbf{m g} / \mathbf{L})\end{array}$ & $\begin{array}{l}\text { NO3 } \\
(\mathbf{m g} / \mathbf{L})\end{array}$ \\
\hline AG1 & 2.01 & 2.71 & 5.32 & 4.01 & 0.10 & 1.31 & 73.20 & 17.24 & 36.00 & 3.82 \\
AG2 & 2.12 & 2.83 & 5.51 & 4.00 & 0.10 & 1.10 & 73.20 & 11.64 & 28.80 & 4.39 \\
AG3 & 2.00 & 2.54 & 5.56 & 3.94 & 0.10 & 1.02 & 61.00 & 7.54 & 36.00 & 1.04 \\
AG4 & 2.03 & 2.83 & 5.52 & 4.19 & 0.11 & 1.01 & 73.20 & 11.21 & 36.00 & 4.96 \\
AG5 & 2.00 & 2.94 & 5.45 & 3.97 & 0.10 & 1.00 & 73.20 & 193.11 & 28.80 & 2.43 \\
AG6 & 2.13 & 2.81 & 5.61 & 4.12 & 0.10 & 1.01 & 97.60 & 5.17 & 36.00 & 10.19 \\
AG7 & 2.00 & 2.96 & 5.80 & 4.34 & 0.11 & 1.01 & 85.40 & 1.29 & 36.00 & 6.35 \\
AG8 & 2.02 & 2.94 & 5.56 & 4.21 & 0.10 & 1.00 & 61.00 & 7.54 & 28.80 & 8.23 \\
AG9 & 2.01 & 2.65 & 5.78 & 4.02 & 0.11 & 1.03 & 73.20 & 5.82 & 43.20 & 0.30 \\
AG10 & 2.00 & 2.45 & 5.72 & 4.00 & 0.10 & 1.01 & 85.40 & 9.05 & 43.20 & 3.98 \\
AG11 & 1.95 & 2.63 & 4.93 & 4.01 & 0.10 & 1.00 & 61.00 & 9.27 & 43.20 & 2.18 \\
AG12 & 2.12 & 2.81 & 5.24 & 4.00 & 0.21 & 1.01 & 85.40 & 11.85 & 28.80 & 0.22 \\
AG13 & 2.00 & 2.63 & 4.97 & 3.86 & 0.11 & 1.00 & 61.00 & 5.82 & 28.80 & 0.79 \\
AG14 & 2.12 & 2.82 & 5.10 & 4.00 & 0.10 & 0.98 & 73.20 & 10.56 & 36.00 & 0.31 \\
AG15 & 1.94 & 2.56 & 5.45 & 4.10 & 0.22 & 0.86 & 85.40 & 10.12 & 36.00 & 3.16 \\
\hline Min & 1.94 & 2.45 & 4.93 & 3.86 & 0.10 & 0.86 & 61.00 & 1.29 & 28.80 & 0.22 \\
Max & 2.13 & 2.96 & 5.80 & 4.34 & 0.22 & 1.31 & 97.60 & 193.11 & 43.20 & 10.19 \\
Mean & 2.03 & 2.74 & 5.43 & 4.05 & 0.12 & 1.02 & 74.83 & 21.15 & 35.04 & 3.49 \\
Stdev & 0.06 & 0.16 & 0.27 & 0.12 & 0.04 & 0.09 & 11.17 & 47.71 & 5.35 & 3.00 \\
\hline [36] & & 150 & 200 & & & 0.3 & & 250 & 250 \\
\hline
\end{tabular}

Attempts on major processes controlling River Ose water chemistry were made employing [40] Plot (Fig. 5) and Pearson correlation (Table 3). The data points on the Gibbs diagram (Fig. 5) suggest that River Ose water chemistry was controlled principally by rainfall and to some extent by weathering of rocks. The correlation (Table. 3) revealed that all cations have positive correlation with $\mathrm{HCO}_{3}{ }^{-}$indicating similar source, mostly geogenic source. However, positive correlation of $\mathrm{NO}_{3}^{-}$with $\mathrm{Ca}^{2+}, \mathrm{Mg}^{2+}, \mathrm{Na}^{+}, \mathrm{K}^{+}$and $\mathrm{HCO}_{3}^{-}$is an indication that majority of these ions originated from anthropogenic activities (i.e. use of fertilizers and sewage pollutants). A clear distinction of the contaminant sources is difficult i.e., agricultural, and/or municipal is difficult to make [41]. $\mathrm{NO}_{3}{ }^{-}$, unlike many ions is not derived from rocks; 
rather it is often associated with faecal and sewage pollution [42]. Thus sources of some of the ions in River Ose water were from wastes deposited on the river channel.

\subsection{Water Quality Index}

Water quality refers to the chemical, physical and biological characteristics of water [43]. It is a measure of the condition of water relative to the requirements of one or more biotic species and or to any human need or purpose [44]. A water quality index (WQI) summarizes large amounts of water quality data into simple terms (e.g., excellent, good, bad, etc.) for reporting to managers and the public in a consistent manner [45]. A water quality index provides a single number that expresses overall water quality at a certain location and time based on several water quality parameters. WQI can be used as a tool in comparing the water quality of different sources and it gives the public a general idea of the possible problems with water in a particular region. The indices are among the most effective ways to communicate the information on water quality trends for the water quality management [46]. Results of the calculated WQI in this research are presented in Table 4 while a standard classification [42, 47] is shown in Table 5. The calculated value of WQI for River Ose water was $89.44 \%$ and fell in the very poor water category. Hence River Ose water was not potable based on WQI calculation.

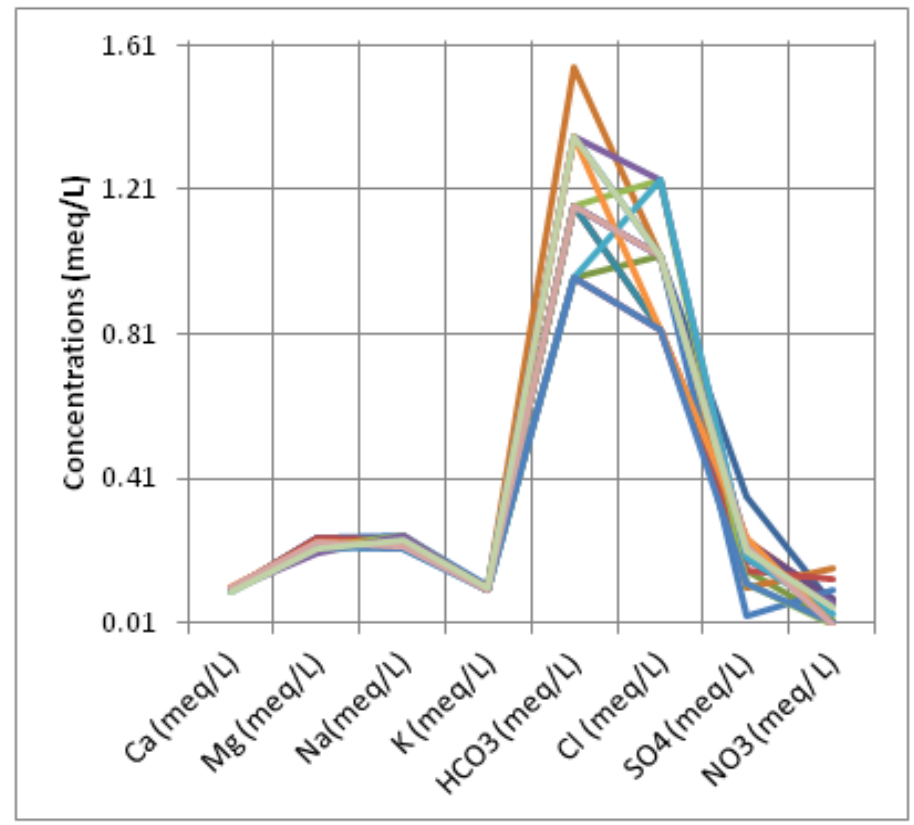

Figure 3: Schoeller Diagram [37].

\subsection{Irrigation Quality Assessment}

River Ose water has been used for irrigation purposes especially during the dry season but the water has not been analyzed for suitability for irrigation purposes. Therefore River Ose water was analyzed for its suitability and usefulness to meet the irrigational needs of farmers and local population of the area. The irrigation quality assessment was carried out employing the under listed irrigation parameters in which all ionic concentrations are in millequivalent per litre: 


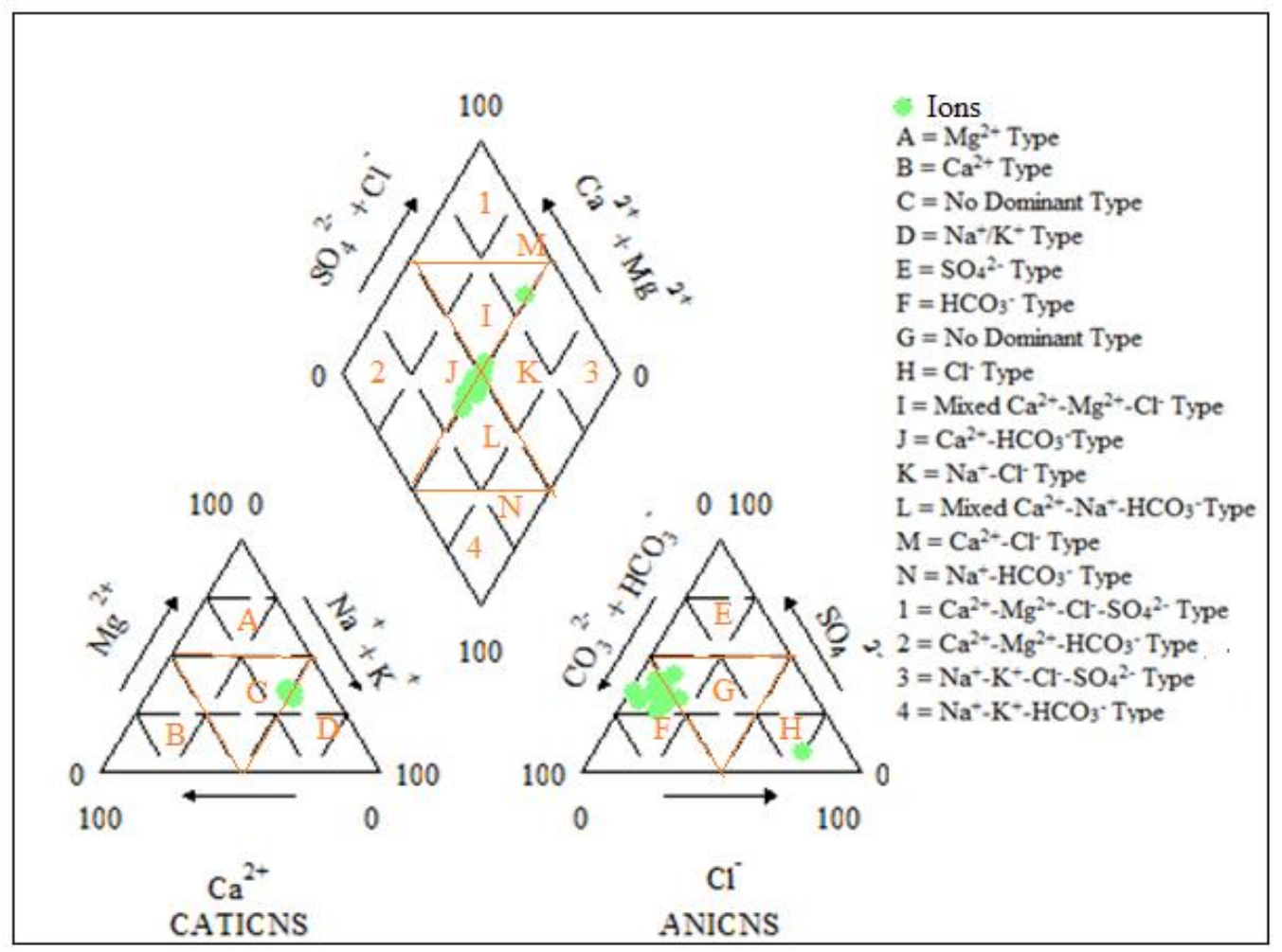

Figure 4: Piper Diagram

a) Sodium Adsorption Ratio (SAR) SAR $=\frac{N a}{\sqrt{(C a}+M g) / 2}$

b)Residual Sodium Bicarbonate $(\mathrm{RSBC})=\mathrm{HCO}_{3}-\mathrm{Ca}$

c) Permeability Index (PI) $=\frac{N a+\sqrt{H} \mathrm{HCOa} \times 100}{\sigma a+M g+N a}$

d) Magnesium Absorption Ratio $(\mathrm{MAR})=\underline{\mathrm{Mg}} * 100$ $\mathrm{Ca}+\mathrm{Mg}$

e) Kelly Ratio (KR)

$$
=\frac{\mathrm{Na}}{\mathrm{Ca}+\mathrm{Mg}}
$$

f) Sodium Percentage $(\% \mathrm{Na})=\frac{\mathrm{Na}+\mathrm{K}}{\mathrm{Ca}+\mathrm{Mg}+\mathrm{Na}+K}$

Result of the estimated irrigation parameters is presented in Table 6. 

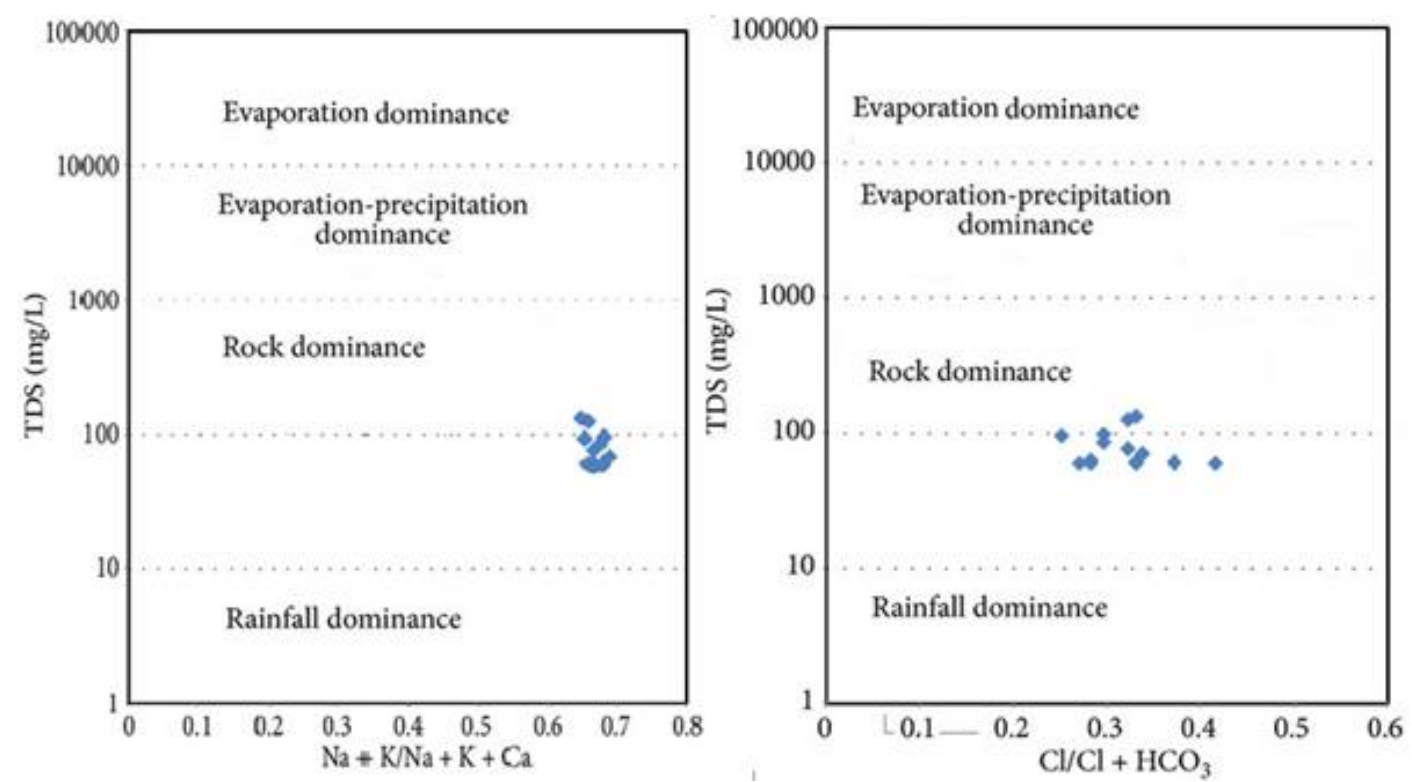

Figure 5: Gibb's Plot

Table 3: Correlation of Ions in River Ose Water

\begin{tabular}{l|llllllllll}
\hline Parameter & $\mathrm{Ca}$ & $\mathrm{Mg}$ & $\mathrm{Na}$ & $\mathrm{K}$ & $\mathrm{HCO} 3$ & $\mathrm{Cl}$ & $\mathrm{SO} 4$ & $\mathrm{NO3}$ & $\mathrm{TH}$ & $\mathrm{TDS}$ \\
\hline $\mathrm{Ca}$ & 1.00 & & & & & & & & & \\
$\mathrm{Mg}$ & 0.43 & 1.00 & & & & & & & & \\
$\mathrm{Na}$ & 0.00 & 0.10 & 1.00 & & & & & & & \\
$\mathrm{~K}$ & -0.04 & 0.53 & 0.53 & 1.00 & & & & & & \\
$\mathrm{HCO} 3$ & 0.36 & 0.09 & 0.44 & 0.36 & 1.00 & & & & & \\
$\mathrm{Cl}$ & -0.37 & -0.57 & 0.20 & 0.07 & 0.13 & 1.00 & & & & \\
$\mathrm{SO} 4$ & -0.12 & 0.34 & -0.01 & -0.21 & -0.05 & -0.33 & 1.00 & & & \\
$\mathrm{NO} 3$ & 0.15 & 0.40 & 0.46 & 0.69 & 0.39 & -0.08 & -0.12 & 1.00 & & \\
TH & 0.59 & 0.98 & 0.09 & 0.46 & 0.16 & -0.59 & 0.27 & 0.39 & 1.00 & \\
TDS & 0.14 & 0.01 & -0.49 & -0.17 & -0.04 & -0.30 & -0.21 & -0.36 & 0.04 & 1.00 \\
\hline
\end{tabular}

\subsubsection{Sodium adsorption ratio (SAR)}

The excess of $\mathrm{Na}^{+}$with $\mathrm{Ca}^{2+}$ and $\mathrm{Mg}^{2+}$ is examined using SAR [48]. Excess $\mathrm{Na}^{+}$in water causes reduction of permeability of the water and continuous use of such water will lead to reduction in soil infiltration and percolation rates. Also, there will be soil crusting, poor aeration and invariably, poor seedling [53]. The SAR for River Ose water ranged from $0.54-0.64$ (Table 6) and are all less than 10 indicating that River Ose water was excellent for irrigation purposes [48].

Table 4: WQI parameters of River Ose water

\begin{tabular}{|c|c|c|c|c|c|c|c|c|}
\hline Parameters & $\begin{array}{l}\text { Observed } \\
\text { Value (Vi) }\end{array}$ & $\begin{array}{l}\text { std } \\
\text { value Si }\end{array}$ & $\begin{array}{l}\text { ideal } \\
\text { value }\end{array}$ & $1 / \mathrm{Si}$ & K & $\begin{array}{l}\text { unit weight } \\
\text { wi }\end{array}$ & $\begin{array}{l}\text { quality } \\
\text { rating qi }\end{array}$ & wiqi \\
\hline $\mathrm{pH}$ & 9.7 & 8.5 & 7 & 0.1176 & & 0.382 & 180 & 68.76 \\
\hline $\mathrm{EC}(\mu \mathrm{S} / \mathrm{cm})$ & 92 & 500 & 0 & 0.002 & & 0.006 & 18.4 & 0.1104 \\
\hline TDS (mg/L) & 59.8 & 250 & 0 & 0.004 & & 0.013 & 23.92 & 0.31096 \\
\hline TH (mg/L) & 15.21 & 300 & 0 & 0.0033 & & 0.011 & 5.07 & 0.05577 \\
\hline $\mathrm{Ca}(\mathrm{mg} / \mathrm{L})$ & 2.03 & 250 & 0 & 0.004 & & 0.013 & 0.812 & 0.010556 \\
\hline $\mathrm{Mg}(\mathrm{mg} / \mathrm{L})$ & 2.74 & 200 & 0 & 0.005 & & 0.016 & 1.37 & 0.02192 \\
\hline $\mathrm{Na}(\mathrm{mg} / \mathrm{L})$ & 5.43 & 50 & 0 & 0.02 & & 0.065 & 10.86 & 0.7059 \\
\hline $\mathrm{K}(\mathrm{mg} / \mathrm{L})$ & 4.05 & 75 & 0 & 0.0133 & 3.252 & 0.043 & 5.4 & 0.2322 \\
\hline $\mathrm{SO} 4$ (mg/L) & 21.15 & 30 & 0 & 0.0333 & & 0.108 & 70.5 & 7.614 \\
\hline $\mathrm{Cl}(\mathrm{mg} / \mathrm{L})$ & 35.04 & 200 & 0 & 0.005 & & 0.016 & 17.52 & 0.28032 \\
\hline NO3 (mg/ L) & 3.49 & 10 & 0 & 0.1 & & 0.325 & 34.9 & 11.3425 \\
\hline
\end{tabular}




\subsubsection{Residual Sodium Bicarbonate (RSBC)}

Residual sodium bicarbonate is used to quantify the effect of $\mathrm{CO}_{3}{ }^{2-}$ and $\mathrm{HCO}_{3}{ }^{-}$on water [54]. When there is excess $\mathrm{HCO}_{3}^{-}$over $\mathrm{Ca}^{2+}$ and $\mathrm{Mg}^{2+}$ there is the tendency to increase the relative proportion of $\mathrm{Na}^{+}$as $\mathrm{Ca}^{2+}$ and $\mathrm{Mg}^{2+}$ may precipitate as carbonates. In this study, RSBC ranged between 0.87 and $1.44 \mathrm{meq} / \mathrm{L}$ with 11 samples $(73.33 \%)$ in excellent irrigation category (RSBC $<1.25 \mathrm{meq} / \mathrm{L})$ and 4 samples $(26.67 \%)$ in marginal/doubtful class $(1.25 \leq \mathrm{RSBC} \leq$ $2.50 \mathrm{meq} / \mathrm{L}$ ). Continuous use of waters with RSBC values $>2.5 \mathrm{meq} / \mathrm{L}$ leads to salt built up which may hinder the air and water movement by clogging the soil pores [55]. None of River Ose water samples fell into this category and the water is safe for irrigation purposes.

Table 5: Classification of water quality based on weighted arithmetic WQI method

\begin{tabular}{ll}
\hline WQI & STATUS \\
\hline $0-25$ & Excellent \\
$26-50$ & Good \\
$51-75$ & Poor \\
$76-100$ & Very Poor \\
\hline
\end{tabular}

Source: [32, 47]

\subsubsection{Sodium percentage ( $\mathrm{Na \%})$}

Sodium percentage evaluates the excess of $\mathrm{Na}^{+}$in water, which can react with the soil to reduce the permeability of the soil and plant growth [56]. The Na\% in River Ose water ranged from $48.75-53.25 \%$ falling in the permissible irrigation class $(40 \leq \% \mathrm{Na} \leq 60)$ [56]. Irrigation water with $\mathrm{Na} \%>60 \%$ may result in the accumulation of sodium and possibly a deterioration of the soil structure, infiltration and aeration [57]. Thus, River Ose water was marginally suitable for irrigation purposes.

\subsubsection{Permeability Index (PI)}

Permeability index assesses the effect of excess $\mathrm{CO}_{3}{ }^{2-}$ and $\mathrm{HCO}_{3}{ }^{-}$on irrigation water. Water with excessive $\mathrm{HCO}_{3}{ }^{-}$and $\mathrm{CO}_{3}{ }^{2-}$, react with $\mathrm{Ca}^{2+}$ and $\mathrm{Mg}^{2+}$ in soil solution to precipitate as calcite and magnesite.

Table 6: Irrigation parameters of River Ose Water

\begin{tabular}{l|llllll}
\hline Code & SAR & $\%$ Na & RSBC & PI & MAR & KR \\
\hline OS1 & 0.57 & 50.59 & 1.06 & 19.33 & 69.20 & 0.71 \\
OS2 & 0.58 & 50.02 & 1.06 & 18.54 & 68.99 & 0.70 \\
OS3 & 0.61 & 52.38 & 0.87 & 17.78 & 67.91 & 0.78 \\
OS4 & 0.58 & 50.74 & 1.06 & 18.67 & 69.91 & 0.71 \\
OS5 & 0.57 & 49.54 & 1.06 & 18.52 & 71.01 & 0.69 \\
OS6 & 0.59 & 50.64 & 1.44 & 21.29 & 68.74 & 0.72 \\
OS7 & 0.61 & 51.18 & 1.26 & 19.44 & 71.15 & 0.73 \\
OS8 & 0.58 & 50.27 & 0.87 & 16.74 & 70.81 & 0.70 \\
OS9 & 0.63 & 52.45 & 1.06 & 18.82 & 68.72 & 0.78 \\
OS10 & 0.64 & 53.59 & 1.26 & 21.06 & 67.12 & 0.82 \\
OS11 & 0.54 & 50.04 & 0.87 & 18.53 & 69.21 & 0.68 \\
OS12 & 0.55 & 49.27 & 1.25 & 20.50 & 68.84 & 0.67 \\
OS13 & 0.54 & 49.68 & 0.87 & 18.38 & 68.67 & 0.68 \\
OS14 & 0.54 & 48.75 & 1.06 & 19.15 & 68.91 & 0.65 \\
OS15 & 0.60 & 52.43 & 1.26 & 21.27 & 68.74 & 0.76 \\
\hline Min & 0.54 & 48.75 & 0.87 & 16.74 & 67.12 & 0.65 \\
Max & 0.64 & 53.59 & 1.44 & 21.29 & 71.15 & 0.82 \\
Mean & 0.58 & 50.77 & 1.09 & 19.20 & 69.20 & 0.72 \\
Stdev & 0.03 & 1.38 & 0.18 & 1.32 & 1.11 & 0.05 \\
\hline
\end{tabular}

This will allow sodium adsorbed to dominate onto the clay surfaces resulting into enhancement of exchangeable sodium percentage of soil which increases sodium hazard and its related problems such as reducing soil permeability, soil aeration, high $\mathrm{pH}$, inhibit root penetration, etc. [58, 59]. Water can be classified as Class I, Class II and Class III orders with regard to permeability index (PI). Class I and Class II waters are categorized as good for irrigation with $75 \%$ or 
more of maximum permeability. Class III waters are unsuitable with $25 \%$ of maximum permeability [60]. From Table 6, the PI values vary from 16.74 to 21.29 (av. 19.20). All water samples fell into the Class III Category of Donnen's chart and were categorized as unsuitable for irrigation

\subsubsection{Kelly's ratio (KR)}

The hazardous effect of sodium on water quality for irrigation usage has been determined in terms of Kelly's ratio [52]. A Kelly's ratio of more than one indicates excessive sodium in water. Therefore, water with a Kelly's ratio less than one are suitable for irrigation while those with a ratio more than one are unsuitable. The KR in this study ranged from 0.65 - 0.82(av. 0.72) (Table, 6) indicating that River Ose water was excellent for irrigation usage.

\subsubsection{Magnesium absorption ratio (MAR)}

Generally, calcium and magnesium maintain a state of equilibrium in most waters and MAR describes the excess amount of $\mathrm{Mg}$ over $\mathrm{Ca}$ and $\mathrm{Mg}$ [51]. More magnesium in water adversely affects the crop yield. MAR for River Ose water ranged from 67.12 - 71.15 (av.69.20). According to [51], MAR>50 is considered harmful and unsuitable for irrigation purpose. Based on MAR, River Ose water was not suitable for irrigation.

\section{CONCLUSION}

River Ose water from Edo State, Southern Nigeria was assessed for quality in terms of its viability for drinking and irrigation purposes. The results revealed that River Ose water was mostly alkaline. All other physico-chemical parameters have low concentrations below approved standard for drinking water. However, River Ose water tested positive to Escherichia coli counts and was not potable. In addition, WQI calculation revealed that River Ose water has very poor drinking quality. Sources of ions in the River were predominantly from rainfall and minor weathering from the bedrocks. River Ose water was classified as having dominant mixed $\mathrm{Ca}^{2+}-\mathrm{Na}^{+}-\mathrm{HCO}_{3}^{-}$water type with mixed $\mathrm{Ca}^{2+}$. $\mathrm{Mg}^{2+}-\mathrm{Cl}^{-}$type in the minority. Irrigation quality parameters (SAR, \% Na, RSBC and KR) indicated that River Ose water was good for irrigation. However, applying the water on salt sensitive plants was not advisable as irrigation evaluation employing PI and MAR showed that River Ose was not suitable for irrigation.

\section{SIGNIFICANT STATEMENT}

The evaluation of the hydrochemistry and Escherichia coli counts of River Ose water has indicated that there are heath implications for people drinking the water untreated. People drinking the water untreated are at health risk of having gastrointestinal diseases in addition to metabolic alkalosis. Irrigation assessment revealed that salt sensitive plants should be avoided if River Ose water is to be used for irrigation in view of the high MAR and PI.

\section{REFERENCES}

[1] Najafzadeh M, Zahiri A, Neuro-fuzzy GMDH-based evolutionary algorithms to predict flow discharge in straight compound channels. J. Hydrol Eng 20(12): 04015035, 2015.

[2] Najafzadeh M, Tafarojnoruz A, Evaluation of neuro-fuzzy GMDH-based particle swarm optimization to predict longitudinal dispersion coefficient in rivers. Environ Earth Sci 75(2):1-12, 2016.

[3] Igbal M, Vicia faba bioassay for environmental toxicity monitoring: a review, Chemosphere, 144, 785-802, 2016.

[4] Majolagbe A. O, Adeyi A. A, Osibanjo O, Vulnerability assessment of groundwater pollution in the vicinity of an active dumpsite (Olusosun), Lagos, Nigeria, Chemistry International, 2, 232-241, 2016.

[5] Jafarinejad S, Control and treatment of sulfur compounds specially sulfur oxides ( $\mathrm{SOx}$ ) emissions from the petroleum industry: A review. Chemistry International 2(4) 242-253, 2016.

[6] Jafarinejad S, Recent developments in the application of sequencing batch reactor (SBR) technology for the petroleum industry wastewater treatment. Chemistry International 3(3) 241-250, 2017.

[7]Majolagbe A. O, Adeyi A. A, Osibanjo 0, Adams A.0, Ojuri 0. 0, Pollution vulnerability and health risk assessment of groundwater around an engineering Landfill in Lagos, Nigeria. Chemistry International 3(1) 58-68, 2017.

[8] Ukpaka C. P, BTX Degradation: The concept of microbial integration. Chemistry International 3(1), 8-18. 2017.

[9] Abbas M, Adil M, Ehtisham-ul-Haque S, Munir B, Yameen M, Ghaffar A, Shar G. A, Tahir M. A, Iqbal M, Vibrio fischeri bioluminescence inhibition assay for ecotoxicity assessment: A review. Science of the Total Environment 626, 1295-1309, 2018.

[10] Merrikhpour H, Jalali M, Geostatistical assessment of solid-liquid distribution coefficients ( $\mathrm{K} \mathrm{d})$ for $\mathrm{Cd}, \mathrm{Cu}, \mathrm{Pb}$ and Zn in surface soils of Hamedan, Iran. Model Earth Syst Environ 1(4):1-9, 2015. 
[11] Noreen M, Shahid M, Iqbal M, Nisar J, Measurement of cytotoxicity and heavy metal load in drains water receiving textile effluents and drinking water in vicinity of drains, Measurement, 109, 88-99, 2017.

[12] Calamari D, Naeve H, (Eds.), Review of pollution in the African aquatic environment. CIFA Technical Paper No. 25, FAO, Rome, 118 pp. 1994.

[13] Aina E. O. A, Adedipe N. O. (Eds.), Water Quality Monitoring and Environmental Status in Nigeria. FEPA Monograph 6, FEPA, Abuja, Nigeria, p239, 1996.

[14] Lloyd B, Helmer R, Surveillance of drinking water quality in rural areas. Longman Scientific and Technical, New York: Wiley, pp34-56, 1992.

[15] AQUASTAT-FAO, Country Fact Sheet, Nigeria. http://www.fao.org/nr/aquastat. Assessed 29th December, 2010.

[16] WHO/UNEP, Water Pollution Control - A Guide to the Use of Water Quality Management Principles, 526 pages ,

1997. Printed in Great Britain by St Edmunds bury Press, Bury St Edmunds, Suffolk, ISBN 0419229108.

[17] Ekiye E, Zejiao L, Water quality monitoring in Nigeria; Case Study of Nigeria's industrial cities. Journal of American Science, Vol. 6, No. 4, pp. 22-28. 2010.

[18] Esoka P. A, Umaru J. M, Industrial effluent and water pollution in Kakuri area, Kaduna South, Nigeria. Journal of Industrial pollution and control, Vol. 22, No 1, pp. 93-100, 2006.

[19] Adebayo O. T, Balogun A. M, Olubiyi O. A, Chemical analysis of some industrial effluents that discharge into Lagos Lagoon, Nigeria. Research Journal of Environmental Sciences, Vol. 1, No. 4, pp. 196-199, 2007.

[20] Jaji M. O, Bamgbose O, Odukoya O. O, Arowolo T. A, Water quality assessment of Ogun River, South West Nigeria. Environmental Monitoring Assessment, Vol. 33, No 1-3, pp. 473-482, 2007.

[21] Mashi S. A, Alhassan, M. M, Effects of wastewater discharge on heavy metals pollution in Fadama soils in Kano City, Nigeria. Journal of Biomedical and Environmental Sciences. Vol. 20, No 1, pp. 70-77, 2007.

[22] Solomon U. U, The state of solid waste management in Nigeria. Waste Management Journal, Vol. 29, No. 10, pp. $2787-2790,2009$.

[23] Ekhator O, Ihenyen J. O, Okooboh G. O, Desmids of Osse River, Edo State, Nigeria. International Journal of Modern Botany, 3(2): 25-31, 2013.

[24] Aribigbola A, Water supply situation in Owo, Ondo State: Implication for sustainable city development in Nigeria. European Journal of Business and Social Sciences, Vol. 1, No. 2, pp 25-34, pp. 25 - 34, 2012.

[25] Omoigberale M. O, Ogbeibu A. E,. Assessing the environmental impact of oil exploration and production on Osse River, Southern Nigeria 1: Heavy metals. Afr. J. Environ. Pollution Health 4(1): 26-32, 2005.

[26] Eaton A. D, Clesceri LS, Rice EW, Greenberg AE (2005) Standard methods for the examination of water and waste water. American Public Health Association (APHA), Washington.

[27] American Public Health Association (APHA), Standard method for the examination of water and waste water (20 edition) Washington D. C, 1998.

[28] Hulton C. S, Higgins C. F, Sharp P. M, ERIC sequences: a novel family of repetitive elements in the genomes of Escherichia coli, Salmonella typhimurium and other enterobacteria. Mol. Microbiol. 5:825-834, 1991.

[29] UNESCO, Water portal newsletter no. 161, Water related diseases. Available at: http://www.unesco .org/water/news/ newsletter/161.shtml. UNESCO, 2007.

[30] Ali N .S, Mo K., Kim M, A case study on the relationship between conductivity and dissolved solids to evaluate the potential for reuse of reclaimed industrial wastewater. KSCE J Civ Eng, 16: 708 -713, 2012.

[31] Horton R. K, An index number system for rating water quality. Journal-Water Pollution Control Federation. 37: 300-305, 1965.

[32] Brown R. M, McClelland N. I, Deininger R. A, O'Connor M. F, Water Quality Index-Crashing, the Psychological Barrier, Proc. 6th Annual Conference, Advances in Water Pollution Research, pp 787-794, 1972.

[33] Tripaty J. K, Sahu K. C, Seasonal hydrochemistry of groundwater in the Barrier Spit system of the Chilika Lagoon, India. J. Environ. Hydrol., 13, pp. 1-9, 2005.

[34] Singh K P, Basant A, Malik A, Jain G, Artificial neural network modeling of the river water quality - a case study. Ecol Model 220(6):888-895, 2009.

[35] Freeze R. A, Cherry J. A, Groundwater. Prentice-Hall, Englewood Cliffs, NJ USA, 1979.

[36] WHO "Guide Lines for Drinking Water Quality", WHO Labrary Cataloguing-in-Publication Data, fourth Edition, Vol.1, Geneve, 2011. http://www.who.int/water_sanitation_health/publications/2011/dwq_chapters/en/index.html

[37] Schoeller H, "Salinity of groundwater, evapotranspiration and recharge of aquifers ". IASH pulls. France, 1960.

[38] Piper A. M, "A graphic procedure in the geochemical interpretation of water analysis", American Geophysical Union Transactions, Vol.25, pp.914-923, 1944.

[39] Ghoraba S. M, Khan A. D, Hydrochemistry and Groundwater quality assessment in Balochistan province, Pakistan, IJRRAS 17 (2), pp. 185 - 199, 2013.

[40] Gibbs R. J, Mechanisms controlling world water chemistry. Science 17:1088-1090, 1970.

[41] Gold M. H, Wariishi H, Valli K, in Biocatalysis in Agricultural Biotechnology. American Chemical Society, Washington, D. C. (Whitaker J. R, Sonnet P, eds)A CS Symposium Series 389, pp. 127-140, 1989.

[42] Adeyemi G. O, Adesile A. O, Obayomi O. M, Chemical characteristics of some well waters in Ikire, Southwestern Nigeria. Water Resources Journal of the Nigerian Association of Hydrogeologists (NAH), Vol. 14, pp. 12-18, 2003. 
[43] Diersing and Nancy, Water Quality: Frequently asked questions, Florida Brooks National Marine Sanctuary, Key West, FL, 2009.

[44] Johnson D. L, Ambrose S. H, Bassett T. J, Bowen M. L, Crummey D. E, Isaacson J. S, Johnson D. N, Lamb P, Saul M, Winter-Nelson A. E, "Meanings of environmental terms", Journal of Environmental Quality, 26, pp 581-589, 1997.

[45] Hulya B, Utilization of the water quality index method as a classification tool, Environmental Monitoring and Assessment, 167, pp 115-124, 2009.

[46] Jagadeeswari P. B, Ramesh K, Water Quality Index for Assessment of Water Quality in South Chennai Coastal Aquifer, Tamil Nadu, India, International Journal of Chem. Tech Research, 4 (4), pp 1582-1588, 2012.

[47] Chatterjee C, Raziuddin M, Determination of water quality index of a degraded river in Asanol Industrial area, Raniganj, Burdwan, West Bengal, Nature, Environment and Pollution Technology, 1 (2), pp 181-189, 2002.

[48] Richards L. A, Diagnosis and improvement of saline and alkali soils, U.S.D.A handbook, Vol.60, 160 p, 1954.

[49] Gupta S. K., Gupta I. C, Management of Saline Soil and Water. Oxford and IBH Publication. Co. New Delhi, India, pp. 399. 1987.

[50] Doneen L.D, Water quality requirement for agriculture. In Proc. National Sym [C]. pp.213-218, 1966. Quality Standards for Natural Waters. University of Michigan.

[51] Raghunath I. I. M, Groundwater. Second edition; Wiley Eastern Ltd, New Delhi, India, 1987.

[52] Kelly W. P, Use of Saline Irrigation Water. Soil Sci. Vol. 95(4):pp. 355-391, 1963.

[53] Lesch S. M, Suarez D. L, A short note on calculating the adjusted SAR Index. Am Soc Agric Biol Eng 52(2):493496, 2009.

[54] Eaton F. M, Significance of carbonates in irrigated waters. Soil Sci 69:127-128, 1950.

[55] Nishanthiny S. C, Thushyanthy M, Barathithasan T, Saravanan S, Irrigation quality based on hydrochemical analysis, Jaffna, Sri Lanka. American-Eurasian Journal of Agriculture and Environmental Science. 7(1): 100 - 102, 2010. [56] Wilcox L. V, Classification and uses of irrigation waters. US Dept. Agric Circular No. 969, Washington, DC, 1955 [57] Hakim M. A, Juraimi A. S, Begum M, Hasanuzzaman M, Uddin, M. K, Islam M. M, Suitability evaluation of groundwater for irrigation, drinking and industrial purposes. Am. J. Environ. Sci., 5: 413-419, 2009.

[58] Domenico P. A, Schwartz F. W, Physical and chemical hydrogeology. John Wiley and Sons, New York, 1990.

[59] Todd D. K, Mays L. W, Groundwater hydrology. 3rd edn. Wiley, Hoboken, NJ, 656, 2005.

[60] Doneen L. D, Water quality for agriculture. Department of Irrigation, University of California, Davis. $48,1964$. 